\title{
DEBT SUSTAINABILITY IN HISTORICAL PERSPECTIVE: THE ROLE OF FISCAL REPRESSION
}

\section{Mauricio Drelichman}

The University of British Columbia and CIFAR

\author{
Hans-Joachim Voth \\ ICREA/Universitat Pompeu Fabra
}

\begin{abstract}
This article examines the debt history of two contenders for European hegemony: 16th-century Spain and 18th-century Britain. We analyze their fiscal behavior using measures of overborrowing and fiscal policy functions. Our results suggest that stringency was not key for Britain's success in avoiding default. Instead, fiscal repression allowed the United Kingdom to borrow at below-market rates, thereby outspending its continental rivals. (JEL: E4, F41, N23)
\end{abstract}

\section{Introduction}

Debt sustainability matters. Sovereign defaults are often cataclysmic events involving widespread damage to the financial sector, the economy, and the political and social fabric of countries in trouble. Assessing what level of debt is sustainable therefore carries special importance. Toward this end, the International Monetary Fund (IMF) uses a range of methods (IMF 2003). These assessments can lead to austerity programs involving wrenching fiscal adjustments (Stiglitz 2003) both before and after crises.

We analyze two historical cases using the existing metric for debt sustainability. We focus on hegemonic powers of their time, 18th-century Britain and 16th-century Spain. Both had access to advanced financial markets and networks, and their finances were under severe pressure as a result of constant warfare. One country became a synonym for fiscal disaster: Spain is a record-holder for default, reneging 13 times on its debts between 1500 and 1900. Philip II started this tradition, going bankrupt four times during his reign (Braudel 1966). Britain, in contrast, not only prevailed in early modern power struggles, but also emerged without defaults and with a widely admired fiscal structure.

\footnotetext{
Acknowledgments: We thank Leandro Prados de la Escosura, Sergio Schmuckler, and Jaume Ventura for valuable discussions, as well as Isaac Holloway for research assistance. Participants at the 2007 EEA meetings in Budapest and an anonymous referee helped us to clarify our argument. This research was supported by SSHRC, CREI (Barcelona), and the Spanish Ministry of Education. E-mail addresses: Drelichman: drelichm@interchange.ubc.ca; Voth: voth@mit.edu
} 
We are not the first historians to analyze these two cases. Britain is traditionally seen as a paragon of fiscal virtue. Scholars have stressed the government's willingness to increase fiscal pressure as debts escalated during the 18th century (Brewer 1990). Others have pointed to the United Kingdom's solid institutions as the deeper cause of its ability to borrow without any difficulty (North and Weingast 1989). Finally, some scholars have emphasized the deep, liquid financial markets that emerged after 1700, a "financial revolution" that followed the Glorious Revolution (Dickson 1967; Ferguson 2002). Spain, on the other hand, is traditionally seen as being hopelessly overstretched, both financially and militarily (Kennedy 1987). Because it was almost continuously at war, its fiscal position is normally described as beyond repair, a view that is apparently confirmed by the frequency with which Philip II had to reschedule his obligations (Thompson 1994).

We will use two popular measures of debt sustainability to shed additional light on these apparently polar opposite cases: an indicator of overborrowing, as used by the IMF (2003), and the Bohn (1998) measure of the fiscal response to accumulating debts. We then conclude with some comments on what the historical record can teach us about the emergence of sustainable debts.

\section{Indebtedness and Surpluses}

The IMF recently presented simple estimates of overborrowing, calculated by taking averages of the primary surplus, interest rates, growth rates, and the debt stock. The sustainable debt level was then calculated as

$$
D^{*}=P S /(r-g)
$$

where $D^{*}$ is the sustainable debt level, PS the primary surplus, $r$ the interest rate, and $g$ the growth rate of gross domestic product (GDP). Actual debt levels $D_{t}$ are then compared with $D *$. The IMF found that industrial countries had debt levels broadly in line with the long-term sustainable ones. By the same yardstick, there is evidence that many emerging countries overborrow: the net present value of their future surpluses is less than the debt stock. Industrial countries have an overborrowing ratio around 1 (suggesting no overhang), but the ratio for Latin American countries is 2.5, and for those with a history of defaults, 3.5 (IMF 2003). Such high ratios imply that a sharp fiscal adjustment is necessary to make debt burdens bearable. This gives strong analytical support to typical "fiscal austerity" packages, as prescribed by the IMF in numerous recent financial crises around the globe.

We begin by analyzing the Spanish case. We draw on a new, comprehensive dataset of Spain's fiscal position (Drelichman and Voth 2007). For the main estimate, we combine this with the new GDP estimates by Álvrez Nogal and Prados 
de la Escosura (2007). ${ }^{1}$ For the period as a whole, average debt levels are about equal to the maximum sustainable debt level, despite constant wars and relatively high interest rates. The second half of the 16th century saw what historians call the "price revolution," with metal imports from the Indies pushing up prices. The fact that $D^{*}$ approaches half of GDP is partly a consequence of this inflation, which boosted nominal GDP and eroded the real value of debt.

The average for the period as a whole hides substantial variation. During the final decade of Philip II's reign, when debt levels reached 62\% of GDP, the rise in the primary surplus generated a $D^{*}$ of $60 \%$. Given these figures, it is hard to conclude that Habsburg Spain overborrowed. However, if we use the alternative GDP estimates compiled by Carreras (2003), then this is not so clear. Because of lower growth, debt levels now exceed the sustainability threshold by more than $10 \%$.

In contrast, Britain appears to have overborrowed in terms of the IMF measure. Its debt level was 10 percentage points higher than could comfortably be serviced, despite low interest rates. The period estimate masks sharp swings of the primary balance from surplus in peacetime to deficit in wartime. Although many authors have stressed the rise of the tax state in 18th-century Britain, the primary surpluses generated are not impressive compared to those of Philip II. Moreover, Philip's surpluses were all generated during war years; Britain was borrowing to cover interest expenses when at war. If there is one factor that allowed Britain to accumulate larger debts, and to outspend its continental rival, it was lower interest rates. Had Britain had to face the same interest rates as Philip II, it would have been able to borrow not $85 \%$, but only $22 \%$ of GDP, far less than Habsburg Spain. Given that Philip II defaulted four times during his reign, part of the difference in the interest rates may reflect this risk. We return to this issue subsequently.

Modern-day evidence suggests that highly variable government revenues limit the amount of debt a state can take on (IMF 2003). Britain failed not only to pursue particularly stringent fiscal policies, but also to stabilize its revenues. Both Britain and Spain suffered relatively wide swings in tax revenues, with coefficients of variation around 0.12 and 0.18 . Modern economies have a range of 0.02 to 0.2 , with a median of 0.07 . Yet while Philip II could compensate the volatile silver revenues from the Indies with the extreme stability of farmed revenues from Castile, Britain's tax system eschewed the use of farming altogether. This is seen by many historians as a sign of fiscal virtue, but it left Britain with revenues that were hardly more stable than those of Spain two centuries earlier.

The evidence presented so far may seem surprising. Britain, the nation traditionally seen as a paragon of fiscal virtue in the historical literature on sustainable sovereign debt, appears no better-if not worse — than the standard villain in most

1. We use their lower-bound estimates of silver currency per capita incomes, combined with estimates of population size, to derive GDP estimates. 
TABLE 1. Standard indicators of debt sustainability.

\begin{tabular}{lccccc}
\hline & $D$ & $D^{*}$ & $P S$ & $r$ & \multicolumn{1}{c}{$g$} \\
\hline Spain, 1560-1598 & & & & & \\
$\quad$ Main estimate & 42 & 40 & 2.4 & 0.09 & 0.03 \\
$\quad$ Alternative GDP & 47 & 36 & 2.8 & 0.09 & 0.012 \\
Britain, 1698-1794 & & & & & \\
$\quad$ Main estimate & 85 & 74 & 1.65 & 0.035 & 0.0138 \\
War years & 83 & & -1.12 & & \\
Peace years & 87 & 189 & 4.2 & 0.035 & 0.0138 \\
\hline Sources: Bonney (2007), Drelichman and Voth (2007) & & & &
\end{tabular}

Sources: Bonney (2007), Drelichman and Voth (2007).

histories of default. Tax pressure was not markedly higher in Britain. Revenue relative to GDP stood at $8.7 \%$ relative to GDP, compared to between $7.3 \%$ and $7.6 \%$ for Spain. At their peak, both Spain and Britain were generating revenues to the tune of $11 \%$ of GDP. Standard indicators of fiscal rectitude, such as primary surpluses and debt levels, seem to be of little help in understanding the contrasting experiences of Britain and Spain. Given the evidence in Table 1, how can we explain why Spain, and not Britain, became the most frequent serial defaulter in history?

\section{Fiscal Policy Functions}

Traditional debt sustainability analysis attempts to predict whether debt-to-GDP ratios will stabilize or rise in the future, given current policies and a range of possible alternatives. Because we do not know with any degree of precision what a sustainable level of debt for a country is, this approach often leads to conclusions that are much too optimistic (Celasun, Debrun, and Ostry 2007). One alternative is based on fiscal policy rules that ensure sustainability. For example, as Bohn (1998) showed, if the primary surplus increases strongly when debt levels rise, then the discounted present value of surpluses will never be less than the value of outstanding debts.

The Bohn approach has recently been applied more widely to contrast good and bad fiscal policies around the globe (IMF 2003). The IMF concluded that sharp increases of the primary surplus in response to the accumulation of debt is common in industrial countries, but much less frequent in the developing world. Typically, a less developed country (LDC) will raise the primary surplus from $0 \%$ to $3 \%$ when debt increases from $20 \%$ to $50 \%$ of GDP and then leave it largely unchanged. Industrial countries generate higher surpluses throughout, with a $2 \%$ rate when debt is $20 \%$ of GDP that increases to around $8 \%$ when debt reaches $100 \%$ of GDP. 


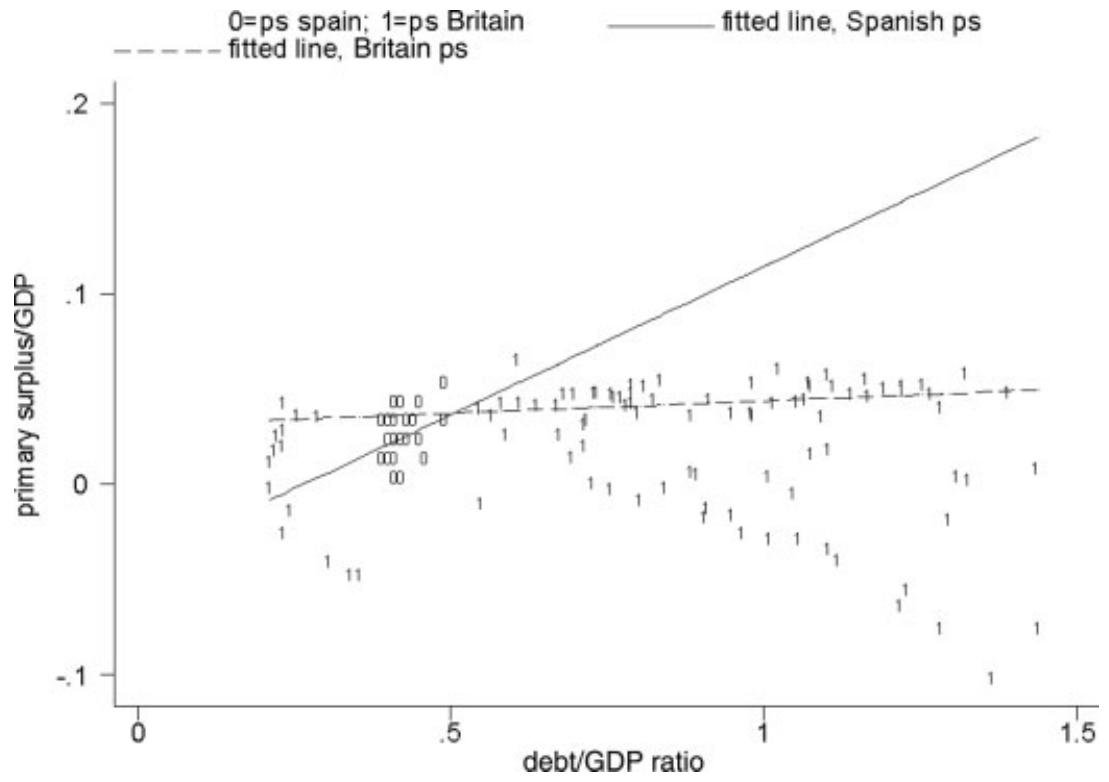

FiguRE 1. Primary surpluses and debt in 16C Spain and 18C Britain.

Source: Authors' calculations.

How did Britain and Spain react to the accumulation of debt? Spain showed a relatively strong response (Figure 1). At a debt level of $20 \%$ of GDP, its primary surplus would be exactly zero, rising to $3.75 \%$ when debt reached $50 \%$ of GDP. Although primary surpluses do rise rapidly with the increase in bonds and loans outstanding, the intercept is actually negative. This means that the Habsburg kings started out with low primary surpluses when their debts were low, raising them to higher levels only when debts grew.

Figure 2 looks at the evolution of Britain's debts and primary surpluses over the 18th century. Primary surpluses increased in absolute value after every war, but they hardly changed at all relative to GDP. In 1700 , Britain had a primary surplus of $7 \%$ of GDP; by 1790 it stood at $7.8 \%$. Given the enormous accumulation of debts relative to GDP, rising from $28 \%$ to $116 \%$, this is surprising. As shown in Figure 1, there is only a mildly upward-sloping relationship between primary surpluses and debt levels in Britain. The regression implies that, when debt/GDP stood at 20\%, the typical surplus was 3.3\% of GDP and rose to $3.6 \%$ when debt reached $50 \%$ of GDP. These values are far below the ones found by the IMF for developed countries today, and at higher levels of indebtedness they are similar to values seen in emerging markets today.

In Figure 3, we repeat the analysis for Spain. Although the primary surplus fluctuates from year to year, it is clearly rising over the period. It peaks at over 


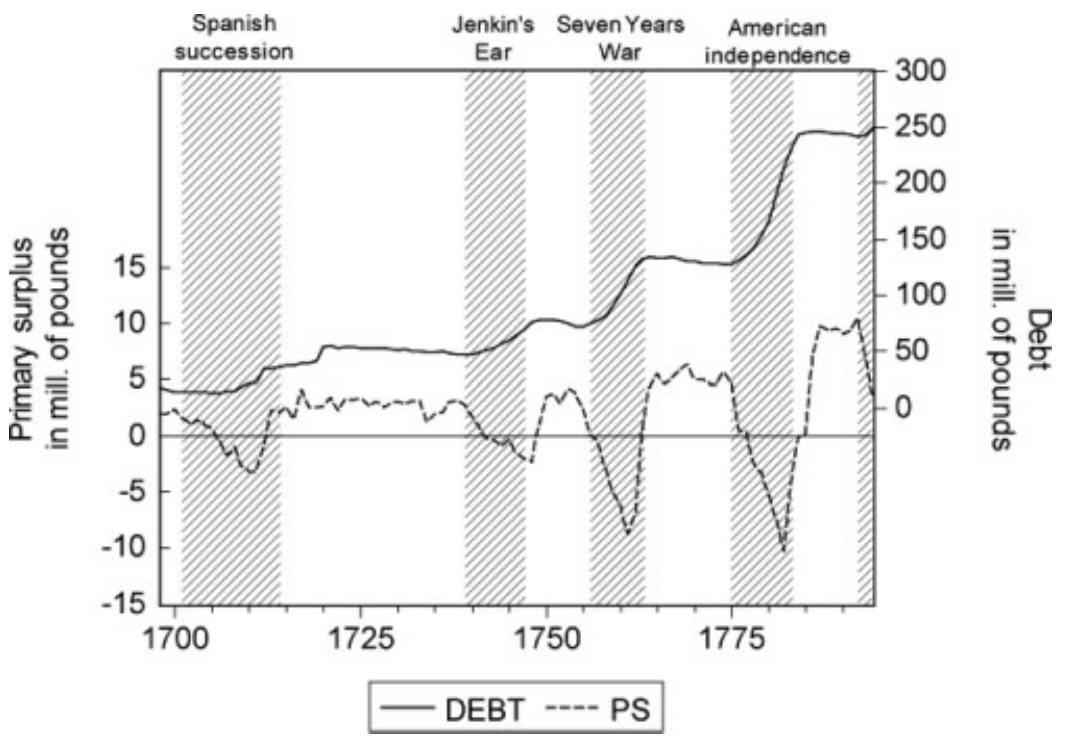

FIGURE 2. Britain's debts and primary surpluses, 1698-1794 (shaded areas represent major wars).

TABLE 2. Fiscal policy reaction functions.

\begin{tabular}{lcccr}
\hline & Beta & $t$-statistic & adj. $R^{2}$ & $N$ \\
\hline Spain, 1560-1598 & & & & \\
OLS & 0.038 & 1.75 & 0.09 & 31 \\
Britain, 1698-1794 & -0.06 & 0.58 & 0.003 & 97 \\
OLS & -0.026 & 2.1 & 0.07 & 46 \\
War years (OLS) & 0.013 & 3.2 & 0.15 & 51 \\
Peace years (OLS) & & & & \\
\hline
\end{tabular}

$3 \%$ at the end of our sample. The increase parallels the rise in the debt/GDP ratio, which shows a rise from $25 \%$ to over $45 \%$.

For a more systematic comparison, we estimate Bohn-style regressions. Table 2 compares the results for Habsburg Spain and Britain. The Bohn coefficient is 0.038 for the reign of Philip II. It is either negative or small and positive for Britain. Even if we restrict the analysis to the peace years, the fiscal reaction to accumulating debts was no more than a third as vigorous as in 16th-century Spain.

Surprisingly, we find that the financially most successful early modern state, Britain, showed almost no fiscal response to changes in debt levels. Instead, it maintained primary surpluses at broadly constant levels, despite the rapid accumulation of a large national debt. We contrast this experience with the much sharper Bohn reaction functions found in a much less successful rival, Habsburg Spain. 


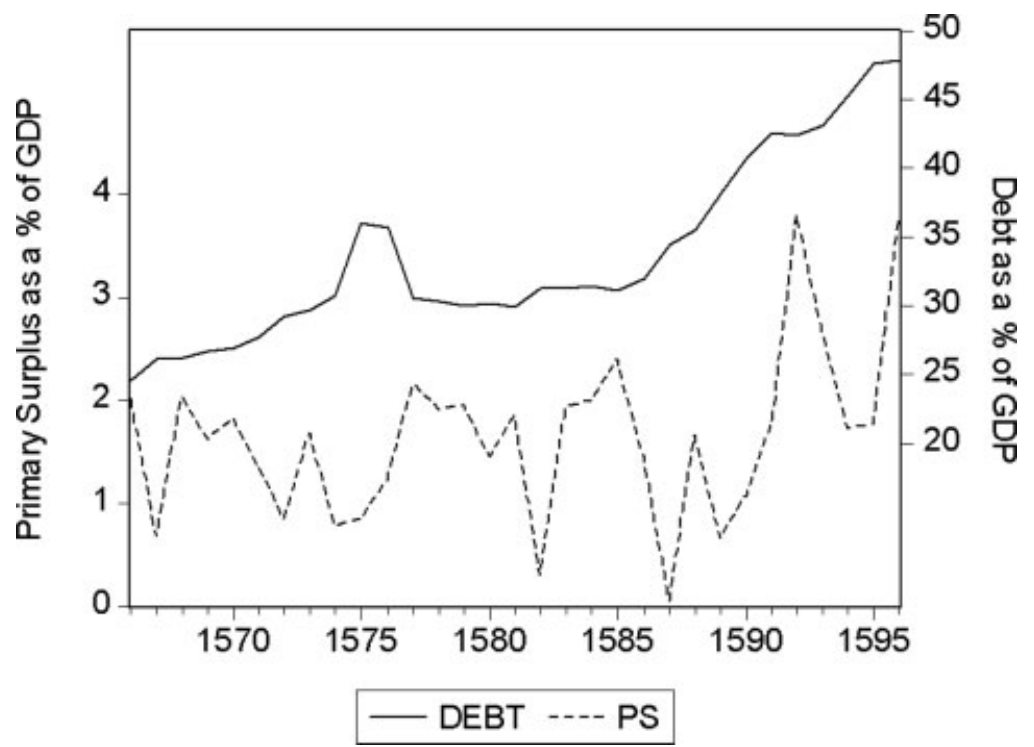

FIGURE 3. Spain's debts and primary surpluses, 1566-1596.

Our results suggest that fiscally weak states may not be capable of generating rapid changes in their surplus and, if they are, success is not assured.

\section{The Role of Fiscal Repression}

The evidence from fiscal policy rules appears to deepen the mystery revealed by overborrowing ratios. Philip II, well known for his lavish spending and repeated bankruptcies, showed fiscal behavior that was highly responsible according to the Bohn approach. The coefficient on debt in the fiscal reaction function is larger than the one for the United States in the 20th century (Bohn 1998), and it was ten times larger than Britain's in the 18th century. What is different is the much lower surplus at low levels of debt. Here, Britain is far above either contemporary LDCs or industrial countries. Britain therefore combined only a minimal response of the primary surplus with a high degree of fiscal conservatism at low levels of indebtedness. One possible interpretation focuses on the fact that peacetime brought reliable primary surpluses that could repay the debt eventually, even at low levels of debt. Because Britain had small debts initially, the willingness to engineer primary surpluses and actually reduce debt levels in the early 18th century (in peacetime) may have created a virtuous cycle: greater commitments led to lower interest rates, which again made repayments easier in peacetime. 
In contrast, Philip II never built a reputation for prudence based on observable fiscal behavior. Interest rates were high and did not decline, making it harder to hit primary surplus figures that rendered debts sustainable. The importance of low interest rates has already been emphasized. It is apparent in the fact that, even though tax pressure was about the same in Great Britain and Spain, the former could still accumulate sustainable debts almost twice as large as its continental rival. The experience of 18th century Britain may suggest a degree of path dependence in debt accumulation and the prospects for repayment. The responsiveness to accumulating deficits, as measured by the Bohn rule and its variations, could be secondary if a country uses its "only chance to leave a first impression" by working hard to engineer surpluses at (initially) low levels of government debt.

We favor an alternative interpretation: financial repression. British fiscal rectitude in the early $1700 \mathrm{~s}$ is an unlikely explanation for the progressively lower interest rates later in the century. When Britain showed the most favorable ratio of primary surpluses to debt, in the early 18th century, its interest rates were not particularly low. In real terms, they were as high as those paid by Philip II. It is only from the 1710s and 1720s onward that British interest rates decline precipitously (Sussman and Yafeh 2006). Because this places the discontinuity a good quarter of a century after the Glorious Revolution, it follows that institutional quality and the restraints imposed by parliamentary rule are also unlikely candidates. Instead of earning a right to lower interest rates, Britain carefully ensured the government's privileged access to citizens' savings. Interest rates were heavily regulated. Usury laws reduced the private sector's competition for funds and created artificially easy borrowing conditions for the government (Temin and Voth forthcoming). It is no coincidence that government debt service became much cheaper only after 1714 , when usury laws were tightened and private lenders were not allowed to charge more than 5\% per year. Other limitations on private loan contracts, such as restrictions on their maximum duration, worked in the same direction. There is ample evidence that government borrowing crowded out private investment on a large scale. Every time military spending surged, private borrowers were effectively shut out of the loan market (Williamson 1984; Temin and Voth 2005).

Simple reflections on investor rationality reinforce this point. At its peak in 1822 , the British government had contracted loans equivalent to nearly three times GDP (Barro 1987). Whenever the country fought a war, debt surged. It increased from 50\% of GDP after the War of the Spanish Succession to $140 \%$ after the Seven Years War and to $275 \%$ after the Napoleonic Wars. Yet repay Britain eventually did, while many of the lenders to Philip II saw their claims reduced as part of the reschedulings. However, it took the long Pax Britannica after 1815 to reduce debts to negligible levels. For 64 out of 97 years in our historical sample from the 18th century, Britain's actual debt level was above the sustainable level, often by a factor of 1.3 or more. Investors buying government debt carrying interest 
rates of 3\% stood a chance of being repaid only if the frequency of war declined sharply relative to their historical experience. Only then, with Britain using large peacetime surpluses to pay down its debts, was there a chance of sustainability. Whether investors could have foreseen peace breaking out with a vengeance in the 19th century is highly doubtful. That the Pax Britannica did take hold after 1815 is no proof of ex ante investor rationality. We simply do not know how much luck at Trafalgar and Waterloo was necessary to ensure the eventual triumph of Britain, but few historians would argue that success was a foregone conclusion at any stage. That investors purchased consols may well tell us more about their lack of alternatives than about the inherent attractions of U.K. government paper. By the same token, Philip's bankers could not foresee the utter ruin of his "Invincible Armada" (its name was not meant ironically).

Thus, part of the contrast in the experiences of Spain and Britain involves access to domestic savings. Whereas Britain could squeeze domestic borrowers and lenders through interest-rate regulations and the like, Philip II had to turn to German, Genovese, and Portuguese bankers. This reliance on imported capital limited the extent to which non-market rates could be obtained for borrowing. ${ }^{2}$ If our interpretation is correct, then both Hanoverian England and Habsburg Spain paid their lenders less than they could have expected in a free-market setting. Whereas Philip periodically chose to reschedule, 18th-century Britain decided to pay its creditors below-market interest rates. In this sense, Britain secured access to resources by means other than taxation: by paying investors in government bonds less than the market rate of return. Although tax pressure was similar in the two countries, fiscal pressure measured comprehensively (including the costs of financial repression) may have been higher in Britain.

\section{Conclusions}

A history of defaults seems to predict future defaults to a substantial extent, above and beyond traditional indicators of debt burdens (Reinhart, Rogoff, and Savastano 2003). Yet where does "debt intolerance" come from? And what can we learn from the emergence of fiscally successful states in early modern Europe? Many accounts of how Britain defeated France and Spain on the financial battlefield, and succeeded in its bid for European hegemony, emphasize fiscal discipline and the willingness to increase taxes after each war (Brewer 1990; Bordo and White 1991; Ferguson 2002).

The data presented in this article call this interpretation into question. Judged by the standards of modern debt sustainability analysis, Britain was not in much

2. The extent to which Britain borrowed abroad is not well established, but it likely did not exceed $8 \%$ to $10 \%$ of total debt (Neal 1990, p. 211). 
better shape than Habsburg Spain. Its debts relative to its sustainable borrowing capacity were not particularly low, and the primary surpluses it generated were not particularly high. Nor did the British government react quickly and decisively to rising debt burdens. The crucial factor that made British borrowing sustainable was a low cost of borrowing.

The markedly lower interest rate faced by the British government was only partly a result of financial discipline and the default-free track record of Britain. Even at the initially low levels of indebtedness, it had generated primary surpluses. If path dependence mattered for creditor perceptions, then the strict financial discipline of the early Hanoverian regime may have had a significant influence on the long-run viability of Britain's finances in spite of a war-induced borrowing binge. We favor an alternative view: early surpluses, the only dimension of traditional debt sustainability analysis in which Britain shines, are probably irrelevant. Instead, a deft dose of financial repression rendered Britain's debt position sustainable. Just as the majority of industrial countries did in the period between 1950 and 1975, Britain did not allow the market to set interest rates on its debt. Instead, a wide range of direct and indirect rules channeled money to the government at preferential interest rates.

In this article we have argued that today's developing countries share many of the same fiscal problems that European states faced between 1500 and 1800, and we explored these similarities. If our argument is so far correct, then neither tough fiscal policy rules nor the standard rules of prudent indebtedness proved decisive in avoiding "debt intolerance" in Britain and Spain. Simplistic calculations of sustainable debt burdens, based on either overborrowing ratios or fiscal policy rules, are not sufficient to assess whether or not debts can be serviced. We suggest that a previously neglected factor, financial repression, was crucial. Given that European countries and the United States engaged in similar practices as recently as the 1960s and 1970s (Wyplosz 2001), we question whether freely set interest rates and free international capital flows are compatible with the emergence of "debt tolerance" in LDCs today.

\section{References}

Álvarez Nogal, Carlos, and Leandro Prados de la Escosura (2007). "The Decline of Spain (1500-1850): Conjectural Estimates.” European Review of Economic History, 11(3), 319366.

Barro, Robert (1987). "Government Spending, Interest Rates, Prices, and Budget Deficits in the United Kingdom, 1701-1918.” Journal of Monetary Economics, 20, 221-247.

Bohn, Henning (1998). "The Behavior of US Public Debt and Deficits." Quarterly Journal of Economics, 113(3), 949-963.

Bonney, Richard (2007). European State Finance Database 1995-2007 [cited 5 September 2007]. Available from http://www.le.ac.United Kingdom/hi/bon/ESFDB/.

Bordo, Michael, and Eugene White (1991). "A Tale of Two Currencies: British and French Finance during the Napoleonic Wars.” Journal of Economic History, 51, 303-316. 
Braudel, Fernand (1966). The Mediterranean and the Mediterranean World in the Age of Philip II, $2 \mathrm{~d}$ rev. ed. William Colins \& Sons.

Brewer, John (1990). The Sinews of Power: War, Money and the English State, 1688-1783. Harvard University Press.

Carreras, Albert (2003). "Modern Spain.” In The Oxford Encyclopedia of Economic History. edited by J. Mokyr. Oxford University Press.

Celasun, Oya, Xavier Debrun, and Jonathan Ostry (2007). "Primary Surplus Behavior and Risks to Fiscal Sustainability in Emerging Market Countries: A "Fan-Chart" Approach." IMF Staff Papers, 53(3), 401-425.

Dickson, P. G. M. (1967). The Financial Revolution in England: A Study in the Development of Public Credit, 1688-1756. St. Martin's Press.

Drelichman, Mauricio, and Hans-Joachim Voth (2007). “The Sustainable Debts of Philip II: A Reconstruction of Spain's Fiscal Position in the Age of Philip II.” Working paper, UPF.

Ferguson, Niall (2002). The Cash Nexus. Money and Power in the Modern World, 1700-2000. Basic Books.

IMF (2003). IMF World Economic Outlook. International Monetary Fund.

Kennedy, Paul M. (1987). The Rise and Fall of the Great Powers: Economic Change and Military Conflict from 1500 to 2000. Random House.

Neal, Larry (1990). The Rise of Financial Capitalism: International Capital Markets in the Age of Reason. Cambridge University Press.

North, Douglass C., and Barry Weingast (1989). "Constitutions and Commitment." Journal of Economic History, 49, 803-832.

Reinhart, Carmen, Kenneth Rogoff, and Miguel Savastano (2003). "Debt Intolerance." Brookings Papers on Economic Activity, 1, 11-74.

Stiglitz, Joseph E. (2003). Globalization and its Discontents. Norton.

Sussman, Nathan, and Yishay Yafeh (2006). "Institutional Reforms, Financial Development and Sovereign Debt: Britain 1690-1790.” Journal of Economic History, 66, 906-935.

Temin, Peter, and Hans-Joachim Voth (2005). "Credit Rationing and Crowding Out During the Industrial Revolution: Evidence From Hoare's Bank, 1702-1862." Explorations in Economic History, 42, 325-348.

Temin, Peter, and Hans-Joachim Voth (2005). "Interest Rate Restrictions in a Natural Experiment: Loan Allocation and the Change in the Usury Laws in 1714." Economic Journal.

Thompson, I. A. A. (1994). "Castile: Polity, Fiscality, and Fiscal Crisis.” In Fiscal Crises, Liberty, and Representative Government, 1450-1789, edited by P. T. Hoffman and K. Norberg. Stanford University Press.

Williamson, Jeffrey (1984). "Why Was British Growth So Slow during the Industrial Revolution?" Journal of Economic History, 44, 687-712.

Wyplosz, Charles (2001). "Financial Restraints and Liberalization in Postwar Europe." In Financial Liberalization: How Far? How Fast?, edited by G. Caprio, P. Honohan, and J. Stiglitz. Cambridge University Press. 